White, C.S., Wielding Social Media in the Cyber-Arena:

Globalism, Nationalism, and Civic Education

\title{
Wielding Social Media in the Cyber-Arena: Globalism, Nationalism, and Civic Education
}

Charles S. White, PhD.*

Executive Director, Social Science Education Consortium

*Corresponding Author: execdirector@ssec-inc.org

Received : 2019-09-03

Accepted : 2019-10-04

How to cite this paper: White, C.S. (2020). Wielding social media in the cyber-arena: Globalism, nationalism, and civic education? Research in Social Sciences and Technology, 5(1), 1-21.

\begin{abstract}
Information technology is a tool, and its effects on global citizenship education (GCED) depend on who uses the technology, how it is employed, and for what purpose. In theory, technology use could provide significant benefits toward achievement of GCED goals. Globalization has demanded an educational response - to prepare the young for productive engagement with the emerging global community. Technology could play a positive role in effective GCED. But globalization has come at a cost; it has produced winners and losers. Among the losers are those economically displaced as manufacturing jobs move elsewhere; they are resentful of foreigner and fearful of an uncertain future. For them, global citizenship is anathema. They are susceptible to manipulation by malign forces eager to exploit any perceived rifts in the postwar world order. For them, technology is a weapon, as easily aimed at the aspirations of GCED as another apparent enemy.
\end{abstract}

Identifying how technology can be employed positively in GCED is important, but not enough. Young people must also understand the conflict between globalization and alt-right nationalist populism, much of it carried out in the cyber-arena of the Internet and social media. New technologies have armed adversaries with tools to manipulate opinion and foment disorder, undermining global citizenship education and Western democracies in general. Young people should be able to recognize the gladiatorial combat between globalization and nationalist populism - between democracy and authoritarianism - in the cyber-arena.

This article explores how technology is a double-edged sword - a tool for good and a tool for mischief. It draws from current research and news reporting on methods and effects of online manipulation. The article concludes by describing international efforts to defend against social media assaults on democracy and by identifying the new knowledge and skills citizens must acquire for positive civic engagement in the global cyber-arena.

Keywords: civic knowledge and skills, democracy, global citizenship, information technology, social media, democracy. 
White, C.S., Wielding Social Media in the Cyber-Arena: Globalism, Nationalism, and Civic Education

\section{Introduction}

The primary aim of Global Citizenship Education (GCED) is nurturing respect for all, building a sense of belonging to a common humanity and helping learners become responsible and active global citizens. GCED aims to empower learners to assume active roles to face and resolve global challenges and to become proactive contributors to a more peaceful, tolerant, inclusive and secure world. Education for global citizenship helps young people develop the core competencies which allow them to actively engage with the world and help to make it a more just and sustainable place. It is a form of civic learning that involves students' active participation in projects that address global issues of a social, political, economic, or environmental nature. (UNAI, n.d., par. 1)

This is how the United Nations describes the scope of its global citizenship education initiative. Successful programs in GCED will foster, among other things, "understanding of multiple levels of identity, and the potential for a 'collective identity' which transcends individual cultural, religious, ethnic or other differences" and "capacities to act collaboratively and responsibly to find global solutions for global challenges, and to strive for the collective good" (UNESCO, 2014, p. 17).

Those who toil in the GCED vineyard aspire to goals articulated decades ago in the aftermath of World War II. In founding the United Nations in 1945, the allied victors recognized that nations could not rely on isolationism as a guarantor of peace and security, and that virulent nationalism inevitably leads to war. Only an interdependent community of nations, with populations capable of global perspectives, and the spread of democratic governance would serve as a solid foundation for a peaceful and prosperous world order. Programs in global studies and global education proliferated from the early 1950s forward (Zong, Wilson, \& Quashiga, 2008). For a half-century after the end of World War II, free trade accelerated economic globalization in the last half century, and new democracies sprouted - especially as the Soviet Union disintegrated in the early 1990s.

In recent decades, despite what appears to be a success story, globalization and democratization now contend with the gale winds of an anti-globalism backlash and authoritarian retrenchment, including efforts to exploit the resulting turmoil to undermine the democratic West. Any discussion of intentional or unintentional inputs into GCED, especially technology, would be incomplete without understanding and responding to this movement.

\section{Globalization and the Populist Response}

At a grand scale, globalization has produced significant benefits to the world community. But globalization has also come at a cost. Table 1 summarizes what analysts have identified as the positive and negative effects of globalization. Usually presented exclusively in economic terms, globalization's cultural and social effects may play an even greater role in the anti-globalist populist movement. 
White, C.S., Wielding Social Media in the Cyber-Arena: Globalism, Nationalism, and Civic Education

Table 1: Globalization's Pros and Cons (Collins, 2015)

\section{Globalization's Pros and Cons}

\section{Pros}

Cons

Economic

\section{Economic}

- Lowers prices for consumers in the developed nations

- Promotes global economic growth

- Creates jobs

- Companies become more competitive

- Creates a world-wide market for companies and consumers who have access to products of different countries, including in the developing world

- Shifts the globe from compartmentalized power sectors to a world-level power capable of addressing global problems and offering global benefits

- Creates speedy travel, mass communication, quick dissemination of information through the internet

- Promotes freer movement of labor

- Promotes the sharing of technology, which accelerates development

- Transnational companies invest in plants in other countries, raising employment, alleviating poverty

Cultural/Social

- Encourages expansion of constitutional democracy

- Promotes influx of information between countries that otherwise had no common ties

- Promotes cultural intermingling and understanding

- Fosters more openness and tolerance among people in other parts of the world, not viewing others as aliens

- Loss of jobs transferred from developed economies to lower cost countries

- Increased trade deficits among developed nations

- Unequal distribution of generated wealth

- Still many trade barriers in the form of Value Added Taxes (VAT)

- Workers in developed countries face pay cuts to avoid jobs leaving the country

- Multinationals accused of exploiting workers and weak environmental laws outside of the developed nations

- Multinational corporations influence national/ international political decisions

- Theft of technology when production goes overseas

- Has failed to address global inequality

- Global spread of communicable diseases

- Social welfare "safety nets" under pressure in developed countries due to deficits and job losses

- De-industrializing of developed nations

- Lower prices have not offset the decline in wages Cultural/Social

- Exposes traditional culture to ideas and values considered undesirable

- Promotes cultural and social change that threatens the status quo and creates uncertainty for the future

- Wage stagnation produces fear of falling behind others who benefit more from globalizations 
White, C.S., Wielding Social Media in the Cyber-Arena: Globalism, Nationalism, and Civic Education

The major stresses of globalization have fallen into two categories: the significant disruption in industrialization and employment patterns, and challenges to the social and cultural status quo and those effects on self-image and rising uncertainty.

\section{Global Economic Disruption}

In the United States, globalization has encouraged a shift from a predominantly manufacturing economy to a service economy. The decline in the coal and steel industries has hit America's heartland hard. Over time, companies have moved operations overseas to take advantage of lower labor costs. The US benefits from that in terms of lower prices when good are imported, but this has been offset by the loss of jobs and poor wage growth.

Other changes to the labor market have unsettled significant portions of the U.S. population. The demand for workers with manufacturing skill and experience has declined, while the demand for knowledge-based workers has increased significantly. The despair of displaced workers has led many to resent immigration, seeing them as competitors for the increasingly scarce jobs. Ironically, the declining number of working-age Americans will require greater immigration to maintain national economic productivity over time. But that is a longer view longer than the next payment deadline for a struggling family. Those most hurt by globalization in the US come to believe that the country is becoming too dependent on outsiders. For them, the web of international trade agreements has compromised our national sovereignty and allowed America to be mistreated by other nations (Mason \& Solis, 2017). Larry Diamond (2018) concluded that "a growing proportion of voters feel threatened by changes they feel unable to control-increasing immigration and cultural pluralism, deepening income inequality and insecurity, de-industrialization, and other challenges to national sovereignty posed by globalization" (par. 11).

\section{Cultural Disruptions and Animosities}

Immigration and migration have produced both economic and cultural disruption world-wide. The increased flow of employment across borders increased to an overwhelming deluge as a result of civil wars and other humanitarian disasters. Europe has been especially affected by the influx of refugees. The strain of accommodating their needs is exacerbated by fears of terrorist groups exploiting the situation for their own ends.

Immigration is perceived by some as a threat to the traditional ethnic dominance within affected nations. In the US, this explains the animosity of some toward inflows of Hispanic immigrants from Latin America; in Europe, it is the influx of Arabs and Muslims that gives rise to rumblings of discontent within sectors of the "dominant" culture.

The particular source of disruption can vary from nation to nation. Sometimes, as above, the blame is assigned to immigration. For others, multiculturalism is the culprit of disorder. For still others, disorder arises from a growing aspiration of a nation's citizens for a more genuine democracy. In all cases, however, the rise of disorder gives strong rulers an excuse to drive a 
White, C.S., Wielding Social Media in the Cyber-Arena:

Globalism, Nationalism, and Civic Education

nation toward greater autocracy. It also tempts our adversaries to exploit disorder and destabilize their foes.

\section{Impatience with Government Response}

Among those adversely affected by globalization there is a strong belief that constitutional democracies and their institutions have not acted quickly enough to solve the problems created by globalization. Moreover, the traditionally dominant race, ethnic group, or class blames constitutional democracy for providing benefits and rights to "others" who haven't earned them. They see themselves as victims, then, at the mercy of elites and the maze of legal and political institutions that seem always in conflict - polarized, partisan, and in gridlock (Levine, 2018). Populists would wish to sweep away all these institutions and legal constraints so that "bold action" can be taken. According to William Galston (2017), "the revolt against [liberal democracy] ... rests on these three complaints: Liberal institutions undermine effective governance, while liberal principles weaken national sovereignty and force citizens to give equal status to people who are unlike them" (p. 31). Consequently, some believe that liberal democracy is suffering a crisis in confidence (Wike \& Fetterolf, 2018)

From these grievances, a populist worldview emerges, as summarized in Table 2. For an indepth description and analysis of contemporary populism, see (Mudde \& Kaltwasser, 2017).

Table 2: Populist Beliefs

\begin{tabular}{||l|l||}
\hline Populists are opposed to: & Populists are: \\
\hline \hline Free trade & Suspicious of foreigners \\
Flexible labor markets & Hyper-patriotic \\
Diversity and immigration & Nationalistic \\
Institutions & \\
International agreements & \\
Elites & \\
Expertise & \\
\hline
\end{tabular}

\section{Populists Backlash in Politics}

The political successes of the contemporary populist movement extend globally, particularly in Europe (Hadiz \& Chryssogelos, 2017; Moffitt, 2018). The vote of the UK to leave the European Union (Brexit) was emblematic of the populist's strong defense of national sovereignty and its fears of the increasing burdens of immigration. Controversy concerning the manner of the UK's exit deepened under British prime minister Boris Johnson (Grant, 2019). Across Europe, new or formally obscure populist parties sprouted up - Podemos in Spain, Syriza in Greece, UKIP in the United Kingdom, and AfD in Germany. The traditional parties were too bureaucratic, too formal, 
White, C.S., Wielding Social Media in the Cyber-Arena: Globalism, Nationalism, and Civic Education

and too slow to react to accelerating change. The new parties seem to be reacting more quickly and more energetically to conflicts in the society, and they provide a megaphone for popular frustrations and anger. They identify with their followers and claim to be the only political movements that truly represent an allegedly homogenous majority (Duerr, 2018).

Embracing the same nationalist, xenophobic, and anti-institutional values, populists in the US have not formed their own political party; third parties have never competed very successfully in America's two-party system. However, like the earlier extremely conservative Tea Party movement nearly ten years ago, American populists have found an uneasy home in the far Right-wing of the Republican party. I say uneasy because the current populist movement's extreme ideology has had the effect of creating rifts in the Republican party. After the highly contentious 2016 presidential campaign, marked by a sophisticated disinformation effort by the Russian government (Carter, 2018), Donald Trump won the Electoral College vote thanks to a mere 77,000 votes across three states.

\section{Why is the Populist Movement a Danger to Democracy?}

Among the targets of the modern populist movements, liberalism looms largest. Populists argue that liberalism and all its institutions and elites do not hear or represent the true voice of the people. Their leader, Donald Trump, claims to be one of them and he alone can best act in their best interests. Consider the implications of this mindset for the preservation of liberal democracy.

\section{A Threat to Limited Government}

What is the essence of liberal democracy? According to Galston (2017), "the phrase 'liberal democracy' combines two distinct ideas. ['Democracy'] stands for a structure of governance in which decisions are made, directly or indirectly, by the people, as well as a conception of politics in which all legitimate power flows from the people. ['Liberal'], by contrast, denotes a particular understanding of politics in which the domain of legitimate public power-even when this power expresses the will of democratic majorities - is inherently limited" p. 11). That is to say, there are some uses of public power that are illegitimate, even in the face of a democratic majority. For populists, these limits on government power to control speech and expression and association and others - reflected in the various institutions, procedures, and laws relevant to those limits - are impediments that slow or even prevent the dramatic and urgent actions populists believe are essential to redress "the People's" complaints and implement their will.

\section{Electoral Autocracy (Illiberal Democracy)}

Regardless of the specific concerns, populist parties and leaders have advocated an abandonment of liberalism, to be replaced by what some refer to as "illiberal democracy" (Zakaria, 1997). Such cases occur when, by popular vote, citizens install a government that suppresses citizens' rights, those elections often marked by massive manipulation. Müller (2018) describes the relationship between liberalism and democracy and how they apply to the 
White, C.S., Wielding Social Media in the Cyber-Arena: Globalism, Nationalism, and Civic Education

growth of illiberal democracies. Citing Zakaria, he uses the nation of Hungary, led by autocrat Victor Orbán, as his example:

Fareed Zakaria, the influential foreign affairs commentator, was among the first to draw a fundamental distinction between liberalism and democracy: the former referred to the rule of law, the latter to the rule of the majority. Leaders with majority backing were creating "illiberal democracies," in which neither political losers nor unpopular minorities could feel safe. This picture is misleading when applied to today's populists like Mr. Orbán. In Hungary, it is not just the rule of law that has been under threat. Rights essential for democracy itself - especially rights to free speech, free assembly and free association - have been systematically attacked. As media pluralism disappears, citizens cannot get critical information to make up their minds about their government's record. (para. 3)

\section{Globalization, Nationalist Populism, and Destabilization in the Cyber-Arena}

The nature of technology's effects on global citizenship education depends largely on how its power is employed. While one can devise ways to harness technology in support of GCED goals, one cannot ignore active efforts to undermine global citizenship and liberal democracy using technology. In the cyber-arena, the ability to identify and defend against malevolent and manipulative cyber assaults is indispensable for robust global citizenship.

\section{Technology as a Tool for Positive Global Citizenship Engagement}

Social media has qualities that can empower global citizenship education, and these we should support and expand. For many, the digital revolution represented the realization of a longdesired democratization of knowledge, defined as "the acquisition and spread of knowledge amongst the common people, not just privileged elites such as clergy and academics" (Wikipedia, n.d.). The people are no longer dependent on and limited to the main news outlets. The decision of what is relevant and important can now reside with the citizens themselves. The same tools that have provided new spaces for information retrieval, creation, and dissemination have also made possible online discussion - locally, nationally, and globally. UNESCO cites an example of this in UNESCO's Global Citizenship Education report:

The Young Masters Programme on Sustainable Development (YMP) has also established a webbased education and learning platform that uses a crowd-learning approach to collect and promote local examples, challenges and success stories. Free of charge for schools, teachers and students, it has been used by participants from 120 countries and around 30,000 students. (2014, p. 29)

In the era of social media, an expanding portion of the public can weigh in on issues that concern them. Anyone with access to social media can express their opinion, comment on the opinion of others, and share their views. Moreover, groups small and large can collaborate on 
White, C.S., Wielding Social Media in the Cyber-Arena: Globalism, Nationalism, and Civic Education

civic projects. Even deliberation, under the right circumstances, can be supported by social media, according to Esau, Friess, and Eilders (2017).

Social media has been used to advocate for certain policies or to seek expanded access to the conditions necessary for democratic citizenship in places where these opportunities are not yet available. The global significance of these developments for revitalizing mature democracies and nurturing the emergence of new democracies should not be underestimated (Shirky, 2011; Ufuophy-Biri \& Ojoboh, 2017). Tucker, Theocharis, and Barbará argue that

Social media have the potential to aid democratic movements by spreading information, reinvigorating participation, and facilitating collective action. In a nutshell, social media can democratize access to information and communication tools. Groups that would ordinarily be censored or silenced can reach a mass public and find it easier to hold powerful elites accountable" (2017, p. 50).

\section{Technology Used to Undermine Truth, Reason, and Confidence}

While benefiting from the positive qualities of social media, citizens and governments around the world are also confronting new challenges. First, the ability to filter the information one receives through social media has contributed to greater polarization within societies. People tend to shut out ideas they disagree with and select only those sites that reinforce their beliefs (Mitchell, Gottfried, Kiley, \& Matsa, 2014). Self-contained echo chambers are a result of the information channels so fine-tuned and immersive that one never needs to leave their selfreinforcing bubbles (Pariser, 2012). Moreover, each of these bubbles has become increasingly polarized, thanks in part to "the greater ease with which extreme voices can make themselves heard in the age of social media" (Mounck \& Eiermann, 2017, para. 15).

Second, as methods of manipulating images, video, and voice grow in sophistication, discriminating between the authentic and the deceptive has become even more burdensome. A case in point is deep fake, or "deepfake," coined in 2017 and described as way to produce very realistic but fake video using a database of readily available photos and an artificial intelligence app that teaches the computer how to superimpose one person's image onto another's. An example that has made the rounds on the Internet is a deepfake of former President Obama. The original FakeApp software was developed as a lark and distributed for free. Not long after it made its way to Reddit and used for a host of inappropriate purposes (Roose, 2018). The relevance to GCED is the potential of the technology, whose quality will make it nearly undetectable over time, to used as a weapon against political leaders running for election and activists advocating for a cause (Sasse, 2018). Deepfakes will take disinformation campaigns, from whatever source, to an entirely different level (Rini, 2019). The potential effects of this technology on politics and citizenship have not gone unnoticed (Boylan, 2018).

Third, internal and external cyber-attacks intent on disrupting and interfering with successful democracies, or frustrating efforts to establish democracy, are a world-wide plague - and are 
White, C.S., Wielding Social Media in the Cyber-Arena: Globalism, Nationalism, and Civic Education

likely to continue (Taylor, 2019). In Indonesia, for example, fake news postings on Facebook have enflamed religious, ethnic, and political tensions (Gabriel, 2017). Fake news can have deadly consequences, where rumors of plots can generate retaliatory violence based on entirely false information. According to one analyst in Sri Lanka, Time and again, communal hatreds overrun the newsfeed - the primary portal for news and information for many users - unchecked as local media are displaced by Facebook and governments find themselves with little leverage over the company. Some users, energized by hate speech and misinformation, plot real-world attacks. (Taub \& Fisher, 2018).

Russian trolling during the 2016 US election demonstrate America's susceptibility to fake news and hoaxes. According to a Timberg and Dwoskin report in the Washington Post (2018), Russian trolls announced 129 phony events during the 2016 campaign, reaching 340,000 users. About 62,500 indicated that they planned to attend. That same report cited the announcement of two competing events scheduled on the same day and time in Houston, Texas, in hopes of fomenting a confrontation. One purportedly came from "Heart of Texas," and the other, from "United Muslims of America," both of which were fictitious creations of Russian. A similar rally in August of 2016 targeted anti-immigrant sentiment in Twin Falls, Idaho - part of a larger and traumatic story for this small town (Dickerson, 2016).

Increased polarization and partisanship. Self-contained echo chambers are a result of the atomization of information and the ability to filter out information that fails to confirm one's existing biases (Pariser, 2012). In the safety of our bubbles, we can enjoy the mutual reinforcement of like-minded people inhabitants (Brady, Wills, Jost, Tucker, \& Van Bavel, 2017). This phenomenon is certainly happening in the US and across the globe. The following summary of a study of Indonesian social media by Lim (2017) can be applied as much to the nations of Europe and North America as it does to Indonesia:

There is no doubt that . . social media . . . contributed to the increasing polarization among Indonesians. ... While encouraging freedom of expression, social media also emboldens freedom to hate, where individuals exercise their right to voice their opinions while actively silencing others. Unraveling the complexity of the relationship between social media and electoral politics, I suggest that the mutual shaping between users and algorithms results in the formation of "algorithmic enclaves" that, in turn, produce multiple forms of tribal nationalism. Within these multiple online enclaves, social media users claim and legitimize their own versions of nationalism by excluding equality and justice for others. (p. 411)

Electoral cyber-manipulation. Social media has also become a force in electoral politics. In Indonesia, for example, where the bulk of social media users reside in urban areas, presidential candidates capitalized on social media, especially Facebook, to promote their candidacies (Nance, 2016; White, 2018). Facebook is particularly influential among 18-24-year-olds, who constitute the largest group of users (Abdillah, 2014). Similar demographics can be found almost universally. 
White, C.S., Wielding Social Media in the Cyber-Arena: Globalism, Nationalism, and Civic Education

In the United States, the Mueller report (Mueller, 2019) provided substantial evidence of Russia's interference in the 2016 election. The current consensus is cyber-attacks will continue and be more aggressive in advance of the 2020 election, involving not only Russia but also China and other bad actors. Unfortunately, voting systems in the US are woefully outdated and susceptible to manipulation (Sanger, Epstein, \& Wines, 2019).

Cyber-troops. The Computational Propaganda Project (CPP) at Oxford University has conducted research on the impact of computer technology on the manipulation of public opinion around the world. In July of 2017, CPP issued a report titled, "Troops, Trolls and Troublemakers: A Global Inventory of Organized Social Media Manipulation." The study concluded that social media "is the primary medium over which young people around the world develop their political identities and consume news. However, social media platforms like Facebook and Twitter have also become tools for social control" (Bradshaw \& Howard, 2017). The report focused narrowly on the global rise of "cyber troops," teams established by governments, the military, or political parties to manipulate public opinion. ${ }^{1}$

First recognized in 2010, details of cyber troop activity were available from twenty-eight countries as of 2017, from both authoritarian and democratic regimes. The former focus almost exclusively on domestic public opinion, with an aim to disrupt the political opposition or to use "astroturfing" methods to create artificial support for government policies or against the opposition by flooding the cyber-arena with often bot-driven laudatory posts. Nearly all the democratic regimes deploy cyber troops to influence foreign publics; domestic social media manipulation efforts are concentrated in political parties, especially in relation to elections (Bradshaw \& Howard, 2017, p. 3). Taken to the extremes, cyber troops target individuals for harassment. Sometimes this includes posting photos of dissidents or opposition leaders online and encouraging abuse. In Russia, for example, leaders of the Kremlin-backed Nashi Youth Movement circulated a list of human rights activists, declaring them "the most vile of enemies" (Elder, 2012).

Censoring or blocking access. Terminating or restricting access to the Internet and wireless service is one approach used to starve citizens of relevant news and information needed to participate in civic life (Committee to Protect Journalists, 2019; Editorial Board, 2019). In autocratic regimes, citizen participation beyond obedience is not prized. For example, Russia is taking measures to limit its citizens' access to the web (Doffman, 2019). In China, the so-called "Great Firewall of China" is an effort of the government to block citizens within the country from accessing Internet sites beyond China's borders (Bloomberg QuickTake, 2017). ${ }^{2}$ Meanwhile, the regime uses social media astroturfing to create the appearance of popular support for the government and to harass opposition groups and individuals.

\footnotetext{
${ }^{1}$ The Computational Propaganda Project has also produced a series of reports that provide a broader look at social media use in Russia, Poland, Brazil, Canada, Germany, Ukraine, and Taiwan. See Woolley and Howard (2017).

${ }^{2}$ This Bloomberg QuikTake (2017) reference also contains a graph depicting the comparative Internet openness for countries worldwide. As of 2016, China was the most restrictive. The United States was ranked fourth in Internet openness.
} 
White, C.S., Wielding Social Media in the Cyber-Arena: Globalism, Nationalism, and Civic Education

Fomenting social and political disorder. Perhaps of greatest danger to liberal democracy from misuse of social media comes from efforts to generate social and political disorder. Some of these efforts come from opposing forces within a nation; some come from foreign actors who welcome the chance to destabilize democracies. Social media also can take relatively minor incidences of disorder and magnifying them through false and incendiary language to appear to generate the appearance of great danger, exploiting fear and uncertainty. Regimes that lean toward autocracy use this phenomenon to crack down on a free press and free expression by the people. Locked in an imposed information desert, democratic citizenship worthy of the name withers.

\section{Fighting Back}

According to Sir Tim Berners-Lee, inventor of the World Wide Web, "[t]hrough the use of data science and armies of bots, those with bad intentions can game the system to spread misinformation for financial or political gain" (Berners-Lee, 2017, para. 4). We have ample evidence that this has been happening, certainly from 2012 and likely earlier. One response has been to goad the major social media platforms to remove the most egregious bad actors.

\section{Social Media Platforms Weed Out the Worst Actors}

Investigation of social media misuse in the US during the 2016 election found that the private information of at least 87 million Americas were scrapped from their Facebook profiles. The information was linked to voter information to design a highly targeted disinformation effort (Confessore, 2018). Under considerable public pressure, Facebook founder Mark Zuckerberg announced that 270 Facebook pages and accounts run by the Russian "troll farm" involved in disrupting the 2016 election are being removed (Castillo, 2018). Facebook also added content reviewers to identify accounts engaged in deliberate disruption; as of February 2018, there were 7,500 (Madrigal, 2018). In cases where users have persisted creating chaos through fake news, Facebook and Twitter have taken action. In the case of Twitter, hundreds of fake accounts used to generate and forward automated bots have been deleted (Twitter PublicPolicy, 2018). Twitter has improved the system's ability identify malicious automation. Google has updated its "search quality evaluator guidelines" to do a better job identifying inaccurate information and altering its algorithms to allow more accurate and reliable information to appear higher in its search results (Southern, 2017). These have been positive steps, but new revelations of social media misuse are a news staple. The government is applying additional pressure on social media companies to do more (Scola, 2019).

\section{Controlling Content through Government Action}

Numerous nations are developing policies to combat fake news - some more draconian than others. At the end of February 2018, for example, the Malaysian government sought legislation that would outlaw "fake news" (Reuters Staff, 2018). The law would punish offenders with a 6year prison term. King of Malaysia reportedly pointed to the effects of social media in "forming the values and culture of a society," a sentiment that is hard to dispute. The Malaysian law 
White, C.S., Wielding Social Media in the Cyber-Arena: Globalism, Nationalism, and Civic Education

defines fake news as "any news, information, data and reports which are wholly or partly false, whether in the form of features, visuals or audio recordings or in any other form capable of suggesting words or ideas" (Beech, 2018, para. 11). This would seem to include cases where the originator did not know the information was false, or whether the person had the intent to disrupt or mislead. Opponents of the new law worry that the government will become the sole judge of what is true and acceptable.

The Philippines and Singapore are also considering new legislation of concern to media rights advocates. In the case of Singapore, which already maintains close oversight over the nation's media, a parliamentary committee is studying ways to extend the law beyond existing laws that already address defamation, hate speech, and fake news. Representatives from Facebook, Google, and Twitter have offered their opinions to a committee considering new laws, mostly suggesting that existing laws should be sufficient (Agence-France Presse, 2018).

\section{Fostering a Well-Educated Citizenry}

In its written statement to the Singapore parliamentary committee, the representative from Google argued that "an effective way of combating misinformation is through educating citizens on how to distinguish reliable from unreliable information. . .. [and by] promoting quality journalism to ensure that there is a robust network of fact-checking organisations providing reliable information and debunking falsehoods" (Agence-France Presse, 2018, para. 4). The journalistic response to misinformation and disinformation fall beyond the scope of this article, but that author's former point on educated citizens is spot on.

\section{At the Ramparts: A Technology-Savvy Global Citizenship Education}

The deluge of deliberately false social media posts, combined with the growth in false information coming from political leaders, seem to represent the dawn of a "post-truth" era. The Oxford English Dictionary chose "post-truth" as its 2016 Word of the Year. They define post-truth as "relating to circumstances in which objective facts are less influential in shaping public opinion than emotional appeals" and personal belief (Post-truth declared word of the year by Oxford Dictionaries, 2016). The RAND Corporation in Santa Monica, California, conducted an in-depth study of this post-truth phenomenon and issued a report titled Truth Decay (Kavanagh \& Rich, 2018).

The crisis of truth extends beyond malicious bots and cyberattacks. It extends to explicit efforts at all levels to obscure truth, and more - to make truth obsolete. Dishonesty lies at the heart of corruption; few conditions are as destructive to democracy as government and corporate corruption. Among the virtues on which democracy depends is honesty - in relationships among citizens and in government's relationship to the people. Civic education alone will not reverse this trend and reestablish a commitment to truth. All sectors of society must work together to respect the truth, reject dishonesty, and root out corruption. Schools can insist that civics students and teachers take the time to skillfully assess the veracity of sources and analyze 
White, C.S., Wielding Social Media in the Cyber-Arena:

Globalism, Nationalism, and Civic Education

and debate public issues based on evidence, reason, and civil discourse - even as they acknowledge that some matters generate emotional responses.

\section{Digital Civic/Media Literacy}

Teachers and researchers in the US have begun to recognize that social media has altered the manner and form by which students seek and acquire information (Brainpop Educators, 2019; Journell, 2019; White, 2018). The potential for misinformation and manipulation in the cyberarena mandates that we increase our efforts to prepare skilled online critical thinkers (Wardle \& Derakhshan, 2017). Critical thinking must extend beyond print, television, and official pronouncements to include multimedia settings (Greenfield, 2009; Kahne \& Bowyer, 2017; Kahne, Hodgin, \& Eidman-Aadahl, 2016; Mihailidis \& Thevenin, 2013; Stoddard, 2014). Fortunately we can draw from the research and practice in digital and media literacy to improve our efforts (Aspen Institute Communications and Society Program, 2010). From the field of media literacy, we can draw core questions and concepts (Table 3) to include in the civics curriculum.

Table 3 Media Literacy Questions and Concepts (Center for Media Literacy, 2005)

\begin{tabular}{|c|c|}
\hline Five Key Questions & Five Core Concepts \\
\hline 1. Who created this message? & 1. All media messages are "constructed." \\
\hline $\begin{array}{l}\text { 2. What creative techniques are used to attract my } \\
\text { attention? }\end{array}$ & $\begin{array}{l}\text { 2. Media messages are constructed using a creative } \\
\text { language with its own rules. }\end{array}$ \\
\hline $\begin{array}{l}\text { 3. How might different people understand this } \\
\text { message compared to me? }\end{array}$ & $\begin{array}{l}\text { 3. Different people experience the same media message } \\
\text { differently. }\end{array}$ \\
\hline $\begin{array}{l}\text { 4. What values, lifestyles, and points of view are } \\
\text { represented in, or omitted from, this message? }\end{array}$ & 4. Media have embedded values \& points of view. \\
\hline 5. Why is this message being sent? & $\begin{array}{l}\text { 5. Most media messages are organized to gain profit } \\
\text { and/or power }\end{array}$ \\
\hline
\end{tabular}

Focusing directly on digital media, the Stanford History Education Group at Stanford University developed a battery of assessment tasks (Wineburg, McGrew, Breakstone, \& Ortego, 2016; McGrew, Breakstone, Ortega, Smith, \& Wineburg, 2018) to gauge student competence in analyzing social media communication (see Table 4). They continue to expand the scope of their research and development that serve as a guide to teaching the skills necessary to separate the wheat from the chaff within the cyber-arena. In the deepfake domain, though, even experts are finding it increasingly difficult to identify Al-produced fake videos. Artificial intelligence researchers note that the improving technology tools to create deepfakes is racing ahead faster than fake detection methods (Harwell, 2019). Fortunately, this variety of disinformation and manipulation has not be widely applied in the political realm to date. 
White, C.S., Wielding Social Media in the Cyber-Arena: Globalism, Nationalism, and Civic Education

Table 4 Civic Online Reasoning Assessment Tasks, by grade level (Wineburg et al., p. 6)

\begin{tabular}{|l|l|l|}
\hline \multicolumn{1}{|c|}{ Middle School } & \multicolumn{1}{|c|}{ High School } & \multicolumn{1}{c|}{ College } \\
\hline $\begin{array}{l}\text { News on Twitter } \\
\text { (tweets/trustworthiness) }\end{array}$ & $\begin{array}{l}\text { Argument analysis (two posts from } \\
\text { newspaper comment } \\
\text { section/compare \& evaluate) }\end{array}$ & $\begin{array}{l}\text { Article evaluation (open web } \\
\text { search/website trustworthiness) }\end{array}$ \\
\hline $\begin{array}{l}\text { Article analysis (sponsored } \\
\text { post/reliability) }\end{array}$ & $\begin{array}{l}\text { Facebook news: (blue check/verified } \\
\text { vs fake account) }\end{array}$ & $\begin{array}{l}\text { Research a claim (online search/verify } \\
\text { a claim about a controversial topic) }\end{array}$ \\
\hline $\begin{array}{l}\text { Comment section (post from } \\
\text { newspaper comment section/use in } \\
\text { research }\end{array}$ & $\begin{array}{l}\text { Facebook argument (exchange of } \\
\text { posts/weigh relative strength of two } \\
\text { opposing arguments) }\end{array}$ & $\begin{array}{l}\text { Website reliability (trustworthiness of } \\
\text { website) }\end{array}$ \\
\hline $\begin{array}{l}\text { News search (news article or opinion } \\
\text { column) }\end{array}$ & $\begin{array}{l}\text { Evaluating evidence (photo-sharing } \\
\text { site photo/trust image) }\end{array}$ & $\begin{array}{l}\text { Social media video (identify strengths } \\
\text { and weaknesses) }\end{array}$ \\
\hline $\begin{array}{l}\text { Home page analysis (news } \\
\text { website/identify advertisements }\end{array}$ & $\begin{array}{l}\text { Comparing articles (News story \& } \\
\text { sponsored post/compare reliability) }\end{array}$ & $\begin{array}{l}\text { Claims on social media (tweet/explain } \\
\text { potential as useful information source) }\end{array}$ \\
\hline
\end{tabular}

\section{Improve the Quality of Discussion and Deliberation}

The nature of communication on social media underscores a more general deficit in youth and adult skills involved in discussion and deliberation. On the social media side, researchers investigating the conditions necessary to support high-quality online deliberation have correctly observed that the design of the online space matters. They are working on social media design standards to achieve that goal As I said earlier, it is difficult to separate emotion and reason when addressing deeply felt public issues. Whether online or person-to-person, there are techniques that we can apply in the classroom and among the public generally to allow facts and reason to prevail (Hodgin \& Kahne, 2018) and to maintain civility as we do so. A leading researcher in deliberative civic education, Diana Hess, has observed that students are simply not getting enough instruction and practice in disciplined discussion and deliberation (2009).

\section{Conclusion}

This cautionary picture sketch of the global cyber-arena is intended not to dissuade young people from their engagement as global citizens, but to buttress it. From the commentary above, I conclude with several recommendations for young people to consider as they carry out their civic work online.

- Reject the claim that is no such thing as reliable information. This cedes the argument to those who would have us believe that truth resides not in reason and evidence but in the mind of a demagogue.

- Rigorously verify information, employ reason based on evidence, suspend judgment in the absence of a convincing argument. Expect others to do the same. These skills are in short supply in the cyber-arena, and it is easy to be lost in the maelstrom of irrationality and message-swapping masquerading as discussion.

- Break out of your cyber-bubble and seek out sources of reasoned opposition to your views and beliefs. Hone your skills in critiquing your own positions as you critique others. 
White, C.S., Wielding Social Media in the Cyber-Arena: Globalism, Nationalism, and Civic Education

- Expecting productive deliberation to occur in 140- or 280-character tweets is asking too much of that platform. Paraphrasing the old saying "Use the right technology tool for the right citizenship job."

- Be vigilant in monitoring government efforts to manage the flow of information to the public, whether through limits on social media platforms, concealment of government information the public has a right to know or directing special benefits to news outlets supportive of the current regime.

- Turn some of your global citizenship commitment to supporting good journalism and debunking faux journalism in the US and around the world. Fact-Check Mongolia (Tardáguila \& Flamini, 2019) is one of many examples of determined journalists fighting for democracy. Speak out against efforts to stifle a free press, to demonize and discredit good journalists, and even to imprison journalists.

- Feel free to add to this list.

A robust program in global civic education will include the content, skills, experiences, and principles needed to carry out these tasks and many more. Practice them until they become matters of habit. They will serve as reliable guides for truth seeking and durable shields for combat in the cyber-arena. 
White, C.S., Wielding Social Media in the Cyber-Arena:

Globalism, Nationalism, and Civic Education

\section{References}

Abdillah, L. A. (2014). Indonesian's presidential social media campaigns. Seminar Nasional sistem Informasi Indonesia (pp. 499-504). Surabaya, Indonesia: Association for Information $\begin{array}{llll}\text { Systems Indonesia } & \text { (AISINDO). } & \text { Retrieved }\end{array}$ https://arxiv.org/ftp/arxiv/papers/1409/1409.8372.pdf

Agence-France Presse. (2018, March 22). Facebook, Google warn Singapore against "fake news" law. The Nation. Retrieved from https://tinyurl.com/t6wpddo

Aspen Institute Communications and Society Program. (2010, November). Digital and media literacy: A plan of action. Washington, DC: The Aspen Institute. Retrieved from http://bit.ly/32Yjc6l

Beech, H. (2018, April 2). As Malaysia moves to ban "fake news," worries about who decides the truth. The New York Times. Retrieved from https://tinyurl.com/sxskogg

Berners-Lee, T. (2017, March 12). Three challenges for the web, according to its inventor [Blog]. Retrieved from World Wide Web Foundation: https://tinyurl.com/r7b99hu

Bloomberg QuickTake. (2017, November 17). The Great Firewall of China. Bloomberg News. Retrieved from https://www.bloomberg.com/quicktake/great-firewall-of-china

Boylan, J. F. (2018, October 17). Will deep-fake technology destroy democracy? New York Times. Retrieved from https://tinyurl.com/yb3xahao

Bradshaw, S., \& Howard, P. N. (2017, July 17). Troops, trolls and troublemakers: A global inventory of organized social media manipulation. Working paper no. 2017.12. Oxford, UK: https://tinyurl.com/y8enqm5p

Brady, W. J., Wills, J. A., Jost, J. T., Tucker, J. A., \& Van Bavel, J. J. (2017). Emotion shapes the diffusion of moralized content in social networks. Proceedings of the National Academy of Sciences. doi:10.1073/pnas.1618923114

Brainpop Educators. (2019, September 24). BrainPOP \& iCivics: Building media literacy skills. Retrieved from https://tinyurl.com/w95evlu

Carter, B. (2018, February '17). McMaster: Evidence is "incontrovertible" that Russia interfered in 2016 election. The Hill. Retrieved from https://tinyurl.com/rtrbc6u

Castillo, M. (2018, April 3). Facebook finds more evidence Russian organization is still attempting to sway public opinion, bans accounts. CNBC. Retrieved from https://tinyurl.com/y79q4znc

Center for Media Literacy. (2005). Five Key Questions of Media Literacy. Malibu, CA. Retrieved from http://www.medialit.org/sites/default/files/14B CCKQPoster+5essays.pdf 
White, C.S., Wielding Social Media in the Cyber-Arena: Globalism, Nationalism, and Civic Education

Collins, M. (2015, May 6). The pros and cons of globalization. Forbes. Retrieved from https://tinyurl.com/wjxkf6z

Committee to Protect Journalists. (2019, September 13). Censorship 2.0: \#MostCensored countries use digital and traditional tactics to silence media. The Torch. Retrieved from https://cpj.org/2019/09/censorship-2-0-the-torch.php

Confessore, N. (2018, April 4). Cambridge Analytica and Facebook: The scandal and the fallout so far. New York Times. Retrieved from https://tinyurl.com/y99xep82

Deepfake. (n.d.). In Wikipedia. Retrieved September 2, 2019, from Wikipedia: https://en.wikipedia.org/wiki/Deepfake

Diamond, L. (2015). Facing up to the democratic recession. Journal of Democracy, 26(1), 141155. Retrieved from https://www.journalofdemocracy.org/article/facing-democraticrecession

Diamond, L. (2018). Following the leader: Are people losing faith in democracy? The American Interest. Retrieved from https://www.the-american-interest.com/2018/03/16/peoplelosing-faith-democracy/

Dickerson, C. (2016, September 26). How fake news turned a small town upside down. New York Times Magazine. Retrieved from https://tinyurl.com/y8ahml5s

Doffman, Z. (2019, September 24). Putin begins installing equipment to cut Russia's access to World Wide Web. Forbes. Retrieved from http://bit.ly/2ViVGhK

Duerr, K. (2018). Are Europe's democracies in danger? A view of the populist challenge. In C. S. White (Ed.), Democracy's Discontent and Civic Education: Multiple Perspectives. Charlotte, NC: Information Age Publishing.

Editorial Board. (2015, February 1). The Guardian view of Europe's populists: left or right, they are united by a worrying xenophobia. The Guardian. Retrieved from https://tinyurl.com/vr7olfh

Editorial Board. (2019, September 7). More governments are shutting down the Internet. The harm is far-reaching. The Washington Post. Retrieved from https://wapo.st/2VbC12W

Elder, M. (2012, February 7). Emails give insight into Kremlin youth group's priorities, means. The Guardian. Retrieved from https://tinyurl.com/t2tfrv9

Elpina, Aspan, H., \& Aryza, S. (2018, January). Effect perspective law in the case of social media in Indonesia. IOSR Journal of Humanities and Social Science, 23(1), 27-30. doi:10.9790/0837-2301022730 
White, C.S., Wielding Social Media in the Cyber-Arena: Globalism, Nationalism, and Civic Education

Esau, K., Friess, D., \& Eilders, C. (2017). Design matters! An empirical analysis of online deliberation on difference news platforms. Policy and Internet, 9(3), 321-342. doi:10.1002/poi3.154

Gabriel, R. (2017, January 17). How Indonesian Muslim organizations are fighting back against fake news. VICE Asia. Retrieved from https://tinyurl.com/qq5zbyn

Galston, W. A. (2017, April). The populist moment. Journal of Democracy, 28(2), 21-33.

Grant, J. (2019). Boris Johnson, Brexit, and Britain's Constitutional Quagmire. The Atlantic, August. Retrieved from https://tinyurl.com/y6ay6pd8

Greenfield, P (2009). Technology and informal education: What is taught, what is learned. Science, 323(5910), 69-71.

Hadiz, V. R., \& Chryssogelos, A. (2017). Populism in world politics: A comparative cross-regional perspective. International Political Science Review, 38(4), 399-411. doi:10.1177/0192512117693908

Harwell, D. (2019, June 12). Top Al researchers race to detect 'deepfake' videos: 'We are outgunned'. The Washington Post. Retrieved from https://tinyurl.com/yxcrdxi2

Hess, D E. (2009). Controversy in the classroom: The democratic power of discussion. New York: Routledge.

Hodgin, E. \& Kahne, J. Misinformation in the Information Age: What teachers can do to support students. Social Education, 82(4), pp. 208-211, 214.

Hunnicutt, T., \& Brice, M. (2019, August 30). Democratic National Committee opposes lowa, Nevada vote-by-phone plans. Reuters. Retrieved from https://tinyurl.com/y6pncfb9

Journell, W. (2019). Unpacking fake news: An educator's guide to navigating the media with students. New York: Teachers College Press.

Kahne, J., \& Bowyer, B. (2017). Educating for democracy in a partisan age: Confronting the challenges of motivated reasoning and misinformation. American Educational Research Journal, 54(1), 3-34. doi: 10.3102/0002831216679817

Kahne, J., Hodgin, E., \& Eidman-Aadahl, E. (2016). Redesigning civic education for the digital age: Participatory politics and the pursuit of democratic engagement. Theory \& Research in Social Education, 44(1), 1-35. doi: 10.1080/00933104.2015.1132646

Kavanagh, J., \& Rich, M. D. (2018). Truth decay: An initial exploration of the diminishing role of facts and analysis in American public life. Santa Monica, CA: RAND Corporation. doi:10.7249/RR2314 
White, C.S., Wielding Social Media in the Cyber-Arena: Globalism, Nationalism, and Civic Education

Kreko, P. (2017, November 29). The authoritarian capture of social media. Modern Authoritarian Influence [Blog]. Washington, DC: National Endowment for Democracy. Retrieved from https://www.power3point0.org/2017/11/29/the-authoritarian-capture-of-social-media/

Levine, P. (2018, July 30). From modest civic reforms to a making a stand for democracy [Blog]. Retrieved from https://peterlevine.ws/?p=20215

Lim, M. (2017). Freedom to hate: Social media, algorithmic enclaves, and the rise of tribal nationalism in Indonesia. Critical Asian Studies, 49(3), 411-427. doi:10.1080/14672715.2017.1341188

Madison, J. (2009). The Federalist No. 51. In I. Shapiro, The Federalist Papers (pp. 263-267). New Haven, CT: Yale University Press.

Madrigal, A. C. (2018, February 7). Inside Facebook's fast-growing content-moderation effort. The Atlantic. Retrieved from https://tinyurl.com/y76r3be7

Mason, J. \& Solis, M. (2017, August 28). Globalization on the cheap: Why the U.S. lost its way on trade. Order from Chaos [blog]. Washington, DC: Brookings Institution. Retrieved from https://tinyurl.com/ybgus6nt

McGrew, S., Breakstone, J., Ortega, T., Smith, M., \& Wineburg, S. (2018). Can students evaluate online sources? Learning from assessments of civic online reasoning. Theory \& Research in Social Education, 46, 165-193. doi.org/10.1080/00933104.2017.1416320

Mihailidis, P., \& Thevenin, B. (2013). Media literacy as a core competency for engaged citizenship in participatory democracy. American Behavioral Scientist, 57(11), 1611-1622. doi:10.1177/0002764213489015

Mitchell, A., Gottfried, J., Kiley, J., \& Matsa, K. (2014, October 21). Political polarization \& media habits. Pew Research Center. Retrieved from http://www.journalism.org/2014/ 10/21/political-polarization-media-habits/

Mitchell, A., Simmons, K., Matsa, K. E., \& Silver, L. (2018, January 11). Publics globally want unbiased news coverage, but are divided on whether their news media deliver. Washington, DC: Pew Research Center. Retrieved from https://tinyurl.com/w9r9umd

Moffitt, B. (2018, Winter). The populism/anti-populism divide in western Europe. Democratic Theory, 5(2), 1-6. doi:10.3167/dt.2018.050202

Mounck, Y., \& Eiermann, M. (2017, December 29). 2017 was the year of false promise in the fight against populism. Foreign Policy. Retrieved from http://foreignpolicy.com /2017/12/29/2017-was-the-year-of-false-promise-for-populism 
White, C.S., Wielding Social Media in the Cyber-Arena: Globalism, Nationalism, and Civic Education

Mudde, C., \& Kaltwasser, C. R. (2017). Populism: A very short introduction. New York, NY: Oxford University Press.

Mueller, R. S. (2019). Report on the Investigation into Russian Interference in the 2016 Presidential election. Washington: United States Department of Justice. Retrieved from https://www.washingtonpost.com/graphics/2019/politics/read-the-mueller-report/

Müller, J.-W. (2018, April 5). 'Democracy' still matters. The New York Times. Retrieved from https://www.nytimes.com/2018/04/05/opinion/hungary-viktor-orban-populism.html

Nance, M. (2016). The plot to hack America: How Putin's cyberspies and WikiLeaks tried to steal the 2016 election. New York, NY: Skyhorse Publishing.

Pariser, E. (2012). The filter bubble: How the new personalized web is changing what we read and how we think. New York, NY: The Penguin Press.

Post-truth declared word of the year by Oxford Dictionaries. (2016, November 16). BBC News. Retrieved from http://www.bbc.com/news/uk-37995600

Reuters Staff. (2018, March 5). Malaysia's Najib pushes to outlaw "fake news" before election. Reuters. Retrieved from https://tinyurl.com/rjvyngp

Rini, Regina. (2019, June 10). Deepfakes are coming. We can no longer believe what we see. The Washington Post. Retrieved from https://nyti.ms/2oRN5ps

Roose, K. (2018, March 4). Here come the fake videos, too. The New York Times. Retrieved from https://www.nytimes.com/2018/03/04/technology/fake-videos-deepfakes.html

Sanger, D. E., Epstein, R. J., \& Wines, M. (2019, July 26). States rush to make voting systems more secure as new threats emerge. New York Times. Retrieved from https://www.nytimes.com/2019/07/26/us/politics/states-voting-systems.html

Sasse, B. (2018, October 19). This new technology could send American politics into a tailspin. The Washington Post. Retrieved from https://tinyurl.com/ya3pz6zb

Scola, N. (2019, August 29). FEC chair summons Facebook, Twitter, Google to disinformation session. Politico. Retrieved from https://tinyurl.com/y6tqqzaz

Shirky, C. (2011). The political power of social media. Foreign Affairs, 90(1), pp. 28-41. Retrieved from http://www.jstor.org/stable/25800379

Southern, M. (2017, March 14). Google increases efforts to filter out offensive, upsetting, and inaccurate content. SEJ (Search Engine Journal). Retrieved from

https://tinyurl.com/srccnlj 
White, C.S., Wielding Social Media in the Cyber-Arena: Globalism, Nationalism, and Civic Education

Stoddard, J. (2014). The need for media education in democratic education. Democracy \& Education, 22(1), Article 4.4 Retrieved from https://democracyeducationjournal.org/home/vol22/iss1/4/

Tardáguila, C. \& Flamini, D. (2019, October 2). Mongolia's journalists won't get left behind on the worldwide trend of fact-checking. Poynter Institute. Retrieved from http://bit.ly/353VmrB

Taub, A., \& Fisher, M. (2018, April 21). Where countries are tinderboxes and Facebook is a match. The New York Times. Retrieved from https://tinyurl.com/y89zkqb7

Taylor, M.L. (31 July, 2019). Combating disinformation and foreign interference in democracies: Lessons from Europe. Cybersecurity and Election Interference series. Brookings Institution. Retrieved from https://brook.gs/2o2VC9J

Timberg, C., \& Dwoskin, E. (2018, January 25). Russians got tens of thousands of Americans to RSVP for their phony political events on Facebook. The Washington Post. Retrieved from https://tinyurl.com/y7fq2sbu

Tucker, J. A., Theocharis, Y., Roberts, M. E., \& Barberá, P. (2017). From liberation to turmoil: Social media and democracy. Journal of Democracy, 28(4), pp. 46-59. doi:10.1353/jod.2017.0064

Twitter PublicPolicy. (2018, January 19). Update on Twitter's review of the 2016 U.S. election. [Blog]. Retrieved from https://tinyurl.com/ue3jgvt

Ufuophy-Biri, E., \& Ojoboh, L. (2017). Social media as a tool for political resistance: Lessons from the Arab Spring and the Nigerian protests. Academic Journal of Interdisciplinary Studies, 6(1), 61-66. doi:10.5901/ajis.2017.v6n1p61

UNAI. (n.d.). Global citizenship education. Retrieved August 31, 2019, from United National Academic Impact: https://academicimpact.un.org/content/global-citizenship

UNESCO. (2014). Global citizenship education: Preparing learners for the challenges of the 21st century. Paris: United Nations Educational, Scientific and Cultural Organization. Retrieved August 31, 2019, from https://unesdoc.unesco.org/ark:/48223/pf0000227729

Wardle, C., \& Derakhshan, H. (2017). Information disorder: Toward an interdisciplinary framework for research and policy making. [Report No. DGI(2017)09], Council of Europe, Strasbourg. Retrieved from https://tinyurl.com/ydbdgbh6

White, C. S. (2018). Democracy's pharmakon: Technology as remedy and poison. In C. S. White (Ed.), Democracy's Discontent and Civic Learning: Multiple Perspectives. Charlotte, NC: Information Age Publishing. 
White, C.S., Wielding Social Media in the Cyber-Arena: Globalism, Nationalism, and Civic Education

Wike, R., \& Fetterolf, J. (2018, October). Liberal Democracy's Crisis in Confidence. Journal of Democracy, 29(4), 136-150.

Wikipedia. (n.d.). Democratization of knowledge. Retrieved from https://en.wikipedia.org/wiki/ Democratization of knowledge

Wineburg, S., McGrew, S., Breakstone, J., \& Ortego, T. (2016). Evaluating Information: The Cornerstone of Civic Online Reasoning. Stanford History Education Group. Stanford: Stanford Digital Repository. Retrieved from http://purl.stanford.edu/fv751yt5934

Woolley, S. C., \& Howard, P. N. (2017, July 11). Computational propaganda worldwide: Executive summary. Working Paper 2017.11. (S. C. Woolley, \& P. N. Howard, Eds.) Oxford, UK: Project on Computational Propaganda. Retrieved from https://tinyurl.com/y7lrbb9p

Zakaria, F. (1997, Nov/Dec). The rise of illiberal democracy. Foreign Affairs, 22-43. Retrieved from http://www.jstor.org/stable/20048274

Zong, G., Wilson, A. H., \& Quashiga, A. Y. (2008). Global education. In L. S. Levstik, \& C. A. Tyson (Eds.), Handbook of research in social studies education (pp. 197-216). New York, NY, USA: Routledge. 